\title{
PENGEMBANGAN LEARNING TRAJECTORY POKOK BAHASAN ARITMATIKA SOSIAL DENGAN PENDEKATAN KONTEKSTUAL DI MTSN 2 PADANGSIDIMPUAN
}

Oleh.

Dr. Ahmad Nizar Rangkuti, S.Si, M.Pdi, Eva Khairani 2

\begin{abstract}
The background of the problem in this study is the obstacles experienced by students of class VIII-4 at MTsN 2 Padangsidimpuan when completing the questions in the initial test. Obstacles found include students who are less able to understand the concept of social arithmetic well. Therefore, it is necessary to make an update in student learning activities, especially on the subject of social arithmetic. The formulation of the problem in this study is how the validity of learning trajectory is the subject of social arithmetic using a contextual approach and how practical learning trajectory is the subject of social arithmetic using a contextual approach. The purpose of this development is to know the learning trajectory validity of the subject of social arithmetic by using a contextual approach and knowing the practicalities of learning trajectory the subject of social arithmetic using a contextual approach.

The discussion of this research relates to the field of mathematics. In connection with this, the approach taken is theories related to mathematics teaching and learning. In this case the learning trajectory developed refers to 7 main components of the contextual approach, namely constructivism, asking, finding, learning society, modeling, reflection, and authentic assessment. So that a valid and practical learning trajectory is used for students of MTsN 2 Padangsidimpuan.

The type of research used is design research. Design research is included in qualitative research. Design research is research that places the design process as a strategy to develop a learning path. Trajectory learning designed is validated by 3 validators. The instrument used in this study is observation and questionnaire.
\end{abstract}

Based on the results of the validation of the 3 validators obtained a value of $75.23 \%$ with a valid category. Learning trajectory practices obtained from observations made on student activities from the meeting were $66.125 \%$, $66.625 \%$, and $67.375 \%$. The use of time used is sufficient and the results of 
the questionnaire obtained are $88.70 \%$ in the practical category. Thus, it was concluded that the development of learning trajectory on the subject of social arithmetic in MTsN 2 was aimed at a valid and practical contextual approach.

\section{Abstrak}

Latar belakang masalah dalam penelitian ini adalah hambatan-hambatan yang dialami siswa kelas VIII-4 di MTsN 2 Padangsidimpuan ketika menyelesaikan soal-soal pada tes awal. Hambatan yang ditemukan antara lain siswa kurang mampu memahami konsep aritmatika sosial dengan baik. Oleh karena itu perlu mengadakan pembaharuan dalam aktivitas belajar siswa terutama pada pokok bahasan aritmatika sosial. Rumusan masalah pada penelitian ini adalah bagaimana validitas learning trajectory pokok bahasan aritmatika sosial dengan menggunakan pendekatan kontekstual dan bagaimana praktikalitas learning trajectory pokok bahasan aritmatika sosial dengan menggunakan pendekatan kontekstual. Adapun tujuan pengembangan ini adalah mengetahui validitas learning trajectory pokok bahasan aritmatika sosial dengan menggunakan pendekatan kontekstual dan mengetahui praktikalitas learning trajectory pokok bahasan aritmatika sosial dengan menggunakan pendekatan kontekstual.

Pembahasan penelitian ini berkaitan dengan bidang ilmu matematika. Sehubungan dengan hal itu, pendekatan yang dilakukan adalah teoriteori yang berkaitan dengan belajar mengajar matematika. Dalam hal ini learning trajectory yang dikembangkan mengacu pada 7 komponen utama pendekatan kontekstual, yaitu konstruktivisme, bertanya, menemukan, masyarakat belajar, pemodelan, refleksi, dan penilaian autentik. Sehingga didapatkan learning trajectory yang valid dan praktis digunakan untuk siswa MTsN 2 Padangsidimpuan.

Jenis penelitian yang digunakan adalah penelitian desain. Penelitian desain termasuk kedalam penelitian kualitatif. Penelitian desain adalah penelitian yang menempatkan proses perancangan sebagai strategi untuk mengembangkan suatu lintasan belajar. Learning trajectory yang dirancang divalidkan oleh 3 orang validator. Instrumen yang digunakan pada penelitian ini adalah observasi dan angket.

Berdasarkan hasil validasi dari dari 3 validator diperoleh nilai 75,23\% dengan kategori valid. Praktikalitas learning trajectory yang diperoleh dari 
observasi yang dilakukan terhadap aktivitas siswa dari pertemuan yaitu $66,125 \%, 66,625 \%$, dan 67,375\%. Penggunaan waktu yang digunakan sudah cukup serta hasil nilai angket yang diperoleh adalah 88,70\% dengan kategori praktis. Dengan demikian diperoleh kesimpulan bahwa pengembangan learning trajectory pokok bahasan aritmatika sosial di MTsN 2 padangsidimpuan dengan pendekatan kontekstual valid dan praktis.

Kata Kunci: Learning trajectory, kontekstual, validitas, praktikalitas

\section{PENDAHULUAN}

Matematika merupakan salah satu disiplin ilmu yang dapat meningkatkan kemampuan berpikir dan beragumentasi, memberikan kontribusi dalam penyelesaian masalah sehari-hari dalam dunia kerja, serta memberikan dukungan dalam pengembangan ilmu pengetahuan dan teknologi. ${ }^{1}$ Pembelajaran matematika adalah suatu proses belajar mengajar yang dibangun oleh guru untuk mengembangkan kreativitas berpikir siswa yang dapat meningkatkan kemampuan berpikir siswa, serta dapat meningkatkan kemampuan mengkonstruksi pengetahuan baru sebagai upaya meningkatkan penguasaan yang baik terhadap materi matematika. ${ }^{2}$

Materi aritmatika sosial merupakan salah satu materi dalam pembelajaran matematika. Materi Aritmatika yang disampaikan dalam pendidikan di Sekolah Menengah Pertama yaitu definisi harga penjualan, harga pembelian, untung, rugi, persentase untung, persentase rugi, rabat, bruto, neto dan tara. Aritmatika sosial akan lebih mudah dipelajari jika kita mengaitkan materi tersebut dimulai dari hal yang real sehingga siswa dapat terlibat langsung dalam proses pembelajaran secara bermakna dan dengan mudah menemukan dan memahami konsep tanpa harus menghafal.

Berdasarkan wawancara dengan salah satu siswa kelas VIII-4 di MTsN 2 Padangsidimpuan ditemukan bahwa ketika mendapatkan materi aritmatika sosial di kelas VII, konsep-konsep dalam materi pokok aritmatika sosial misalnya konsep harga jual, harga beli, untung, rugi, bruto, tara dan netto disajikan dengan metode

\footnotetext{
${ }^{1}$ A. Susanto, Teori Belajar dan Pembelajaran di Sekolah Dasar (Jakarta: Kencana Prenada Media Grup, 2013), hlm. 185.

${ }^{2}$ A. Susanto, Op Cit., hlm 187.
} 
ceramah. ${ }^{3}$ Akibatnya tidak terjadi interaksi timbal balik antara guru dengan siswa maupun siswa dengan siswa, sehingga pemahaman konsep-konsep aritmatika yang siswa terima tidak terlalu mendalam dan siswa sulit untuk mengingat kembali materi aritmatika sosial yang sudah siswa pelajari. Padahal materi aritmatika sosial merupakan salah satu materi yang sangat berkaitan dengan aktivitas siswa seharihari. Kemampuan siswa kelas VIII-4 MTsN 2 Padangsidimpuan dalam mengerjakan soal aritmatika sosial juga masih dikategorikan rendah. Hal ini dilihat dari hasil test awal yang di berikan peneliti kepada 39 siswa kelas VIII-4 MTsN 2 Padangsidimpuan. Berdasarkan test awal tersebut, hanya 18 siswa dari 39 siswa yang mendapatkan nilai diatas KKM. Sedangkan Kriteria Ketuntasan Minimal (KKM) mata pelajaran matematika di MTsN 2 Padangsidimpuan adalah 75. Rendahnya hasil belajar siswa pada kelas VIII-4 ini disebabkan karena berbagai hal. Salah satunya disebabkan penggunaan bahan ajar yang kurang maksimal misalnya buku-buku pelajaran yang tidak lengkap akan berdampak terhadap rendahnya hasil belajar siswa. ${ }^{4}$ Untuk ini perlu dilakukan pembaharuan buku ajar yang dapat mendorong keaktifan siswa (student centered).

Berdasarkan analisis peneliti terhadap buku matematika yang digunakan siswa kelas VII semester 2 di MTsN2 Padangsidimpuan, bahwa siswa masih menggunakan buku teks umum yang penyajian materi tersusun sebagai berikut: 1) definisi (pengertian konsep); 2) contoh soal; dan 3) latihan soal. Buku teks umum menjelaskan pengertian (definisi) suatu konsep dalam matematika. Kemudian, memberikan contoh penerapan konsep tersebut, dan diakhiri dengan memberikan soal latihan. Ketiga tahapan penulisan buku teks umum tersebut didominasi oleh pengarang, sedangkan siswa (pembaca) bersikap pasif memahami dan mengerjakan soal yang dijelaskan dan diperintahkan oleh penulis. Selain itu, buku teks umum matematika tersebut tidak memuat soal-soal non rutin serta tidak menantang siswa untuk melakukan kegiatan refleksi, eksperimen, eksplorasi, inkuiri, konjektur, dan generalisasi. Bahan yang disajikan monoton dan soalsoalnya bersifat rutin. Dengan cara penulisan buku teks umum seperti itu, siswa sukar mengembangkan kemahiran matematikanya.

Dalam buku matematika kurikulum kelas VII semester 2, Pada setiap bab dilengkapi dengan peta konsep, pengantar, bagian kegiatan siswa baik eksperimen maupun non eksperimen atau diskusi, latihan soal, rangkuman, evaluasi, dan tugas

${ }^{3}$ Nurul IImi Silitonga, Siswa Kelas VIII-4, Wawancara di MTsN2 Padangsidimpuan, 09 Oktober 2017, pukul 10:30 WIB.

${ }^{4}$ Aunurahman, Op Cit., hlm. 196 
bagi peserta didik. ${ }^{5}$ Namun dalam buku ini hanya memfokuskan penalaran siswa, sehingga siswa yang kemampuan spasialnya (imajinasi) rendah akan merasa kesulitan. Seharusnya dalam aritmatika sosial dilakukan pengaplikasian dengan cara siswa menjadi aktor dengan berperan langsung dalam menyelesaikan masalah aritmatika sosial. Dengan begitu, siswa dapat merasakan bagaimana menjadi seorang penjual dan pembeli sehingga mengetahui bagaimana cara untuk menetapka harga jual, harga beli, mendapatkan keuntuangan dan mengalami kerugian. Siswa yang mengalami secara langsung akan lebih mudah memahami materi dan mengingat konsep aritmatika sosial dan dapat menerapkannya dalam kehidupan sehari-harinya.

Oleh karena itu, peneliti akan mendesain suatu learning trajectory yang sesuai dengan kondisi siswa agar siswa lebih mudah mengerti atau memahami materi yang diajarkan. Learning trajectory adalah urutan pembelajaran yang menggambarkan pemikiran siswa saat proses pembelajaran untuk mendorong perkembangan berpikir siswa agar tujuan pembelajaran matematika siswa sesuai dengan yang diharapkan. Salah satu learning trajectory yang sesuai dengan materi aritmatika sosial adalah dengan menggunakan pendekatan kontekstual. Pendekatan kontekstual adalah konsep belajar yang membantu guru mengaitkan antara materi yang diajarkan dengan situasi dunia nyata siswa dan mendorong siswa membuat hubungan antara pengetahuan yang dimilikinya dengan penerapannya dalam kehidupan siswa sehari-hari. Pendekatan kontekstual dalam pembelajaran memberikan fasilitas kegiatan belajar peserta didik untuk mencari, mengolah, dan menemukan pengalaman belajar yang lebih bersifat konkret (terkait dengan kehidupan nyata) melalui keterlibatan aktivitas peserta didik dalam mencoba, melakukan dan mengalami sendiri.

Siswa lebih mudah mengingat dan memahami pelajaran Matematika jika dia senang melakukan hal tersebut dan disertai dengan pengalaman nyata yang ada di kehidupan sehari-hari. Melalui permainan siswa diharapkan ikut aktif dalam pembelajaran sehingga tanpa disadari anak telah bisa menerapkan konsep dalam pembelajaran Matematika. Permainan tersebut bisa berupa permainan pasaran yang merupakan salah satu permainan tradisional yang biasa dimainkan anak-anak.

Berdasarkan uraian di atas, maka peneliti ingin membahas tentang "Pengembangan Learning Trajectory Pokok Bahasan Aritmatika Sosial dengan Pendekatan Kontekstual di MTsN 2 Padangsidimpuan".

\footnotetext{
${ }^{5}$ Abdul Rahman As'ari, dkk., Matematika SMP/MTs Kelas VII Semester 2 (Jakarta: Kementrian Pendidikan dan Kebudayaan, 2016)
} 
Dari latar belakang yang telah disampaikan di atas, sebagai rumusan masalah utama pada penelitian ini adalah sebagai berikut:

1) Bagaimana validitas learning trajectory pokok bahasan aritmatika sosial dengan pendekatan kontekstual di MTsN 2 Padangsidimpuan?

2) Bagaimana praktikalitas learning trajectory pokok bahasan aritmatika sosial dengan pendekatan kontekstual di MTsN 2 Padangsidimpuan?

Buku ajar yang baik menurut Greene dan Petty adalah sebagai berikut: 1) Menarik siswa, 2) Memberi motivasi siswa, 3) Memuat ilustrasi, 4) Mempertimbangkan aspek-aspek linguistik, 5) Berhubungan erat dengan pelajaran lainnya, 6) Dapat menstimulasi dan merangsang aktivitas siswa, 7) Menghindari konsep-konsep yang samar-samar dan tidak biasa, 8) Mempunyai sudut pandang atau point of view yang jelas dan tegas, 9) Memberi pemantapan, penekanan pada nilai-nilai anak dan orang dewasa, dan 10) Dapat menghargai pribadi-pribadi para siswa. ${ }^{6}$ Ke sepuluh kriteria di atas harus diupayakan penemuannya oleh penulis buku ajar. Di samping itu, penulisan buku ajar perlu memperhatikan kesesuaiannya dengan standar isi dan mengarah kepada tujuan pendidikan, baik tujuan nasional, institusional, maupun tujuan instruksional.

Menurut Simon mengenai konsep hypothetical learning trajectory:

(...) a mathematics teacher will first try to anticipate in advance what the mental activities of the students will be when they will participate in some envisioned instructional activities, and next will try to find out to what extend the actual thinking processes of the students correspond with the hypothesized ones during the enactment of those activities, to finally reconsider potential or revised follow-up activities. To characterize the teacher's thinking, Simon coins the term, 'hypothetical learning trajectory,' which he describes as: 'The consideration of the learning goal, the learning activities, and the thinking and learning in which the students might engage

$(\ldots) .^{7}$

Berdasarkan pernyataan Simon di atas, hypothetical learning trajectory menyediakan guru untuk membuat desain pembelajaran tertentu, sehingga guru dapat memperkirakan dengan baik bagaimana proses belajar yang sedang berlangsung. Hal tersebut dapat ditunjukkan dengan membuat perencanaan

\footnotetext{
${ }^{6}$ Tarigan, Telaah Buku Teks Bahasa Indonesia (Bandung : Angkasa, 1993), hlm. 20.

${ }^{7}$ Koeno Gravemeijer dan Paul Cobb, Educational Design Research Part A: An introduction (Netherlands: SLO, Enschede, 2013), hlm. 82.
} 
pembelajaran yang dilengkapi dengan penjelasan pengajaran di setiap situasi serta keputusan spontan dalam menanggapi pemikiran siswa. Simon juga menyebutkan bahwa hypothetical learning trajectory terbuat dari tiga komponen yaitu tujuan pembelajaran, aktivitas pembelajaran dan proses hipotesis belajar (bagaimana siswa berpikir dan memahami).

Sarama dan Clements (dalam Consortium for Policy Research in Education) mendefinisikan learning trajectories matematika sebagai berikut:

(...) learning trajectories as descriptions of children's thinking and learning in a specific mathematical domain, and a related conjectured route through a set of instructional tasks designed to engender those mental processes or actions hypothesized to move children through a developmental progression of levels of thinking, created with the intent of supporting children's achievement of specific goals in that mathematical domain. ${ }^{8}$

Sarama dan Clements mengatakan bahwa learning trajectories matematika merupakan deskripsi pemikiran dan belajar anak-anak dalam domain matematika tertentu dan menduga lintasan terkait melalui serangkaian tugas intruksional yang telah dirancang. Serangkaian tugas yang telah dirancang tersebut dimaksudkan untuk menimbulkan proses mental anak-anak atau dugaan perilaku yang akan dilakukan oleh anak-anak melalui perkembangan tingkat berpikir mereka dalam rangka mencapai tujuan pembelajaran matematika tertentu.

Seperti halnya Simon, Sarama dan Clements melibatkan tiga komponen utama pada learning trajectory yaitu: 1) Tujuan pembelajaran yang diinginkan; 2) Pengalaman instruksional dan tugas-tugas yang diduga dapat menimbulkan proses mental siswa; 3) Pemikiran dan belajar siswa yang melalui tingkat perkembangan berpikir siswa.

Tahapan Learning Trajectory terdiri dari tiga tahap yaitu: (1) Preliminary Design (Desain Pendahuluan) adalah mengembangkan urutan aktivitas pembelajaran dan mendesain instrumen untuk mengevaluasi proses pembelajaran tersebut. (2) Design Experiment (Percobaan Desain), pada tahap kedua ini, peneliti menguji cobakan kegiatan pembelajaran yang telah didesain pada tahap I. Ujicoba ini bertujuan untuk mengeksplorasi dan menduga strategi dan pemikiran siswa selama proses pembelajaran yang sebenarnya. Tahapan percobaan desain dibagi menjadi 2 siklus, yaitu percobaan pengajaran dan percobaan rintisan.; (3) Retrospective Analysis (Analisis Retrospektif), data yang diperoleh dari aktivitas

8 Phil daro, et al., Learning Trajectories In Mathematics (CPRE, 2011), hlm. 19. 
pembelajaran di kelas atau teaching experiment dianalisis untuk mengembangkan desain pada aktifitas berikutnya. ${ }^{9}$

\section{METODOLOGI PENELITIAN}

Lokasi penelitian ini adalah MTsN 2 Padangsidimpuan yang terletak di Jln. H.T Rizal Nurdin KM. 6,5 gg. Pendidikan dan waktu penelitian ini berlangsung mulai Januari 2017 sampai Mei 2018 yang dilaksanakan di MTsN 2 Padangsidimpuan. Penelitian ini merupakan penelitian research and development.

\section{HASIL DAN PEMBAHASAN}

\section{Deskripsi Data Hasil Belajar Pretest Siswa}

Hasil belajar pretest adalah nilai yang diperoleh siswa kelas VII MTs Negeri Model Padangsidimpuan sebelum pembelajaran diberi perlakuan.

Adapun kriteria penilaian hasil belajar matematika siswa, yaitu:

Tabel 1. Kriteria Penilaian Hasil Belajar Matematika Siswa

\begin{tabular}{|c|c|c|}
\hline No & Interval Nilai & Kategori \\
\hline 1 & $90-100$ & Sangat Baik \\
\hline 2 & $80-89$ & Baik \\
\hline 3 & $70-79$ & Cukup \\
\hline 4 & $60-69$ & Kurang \\
\hline 5 & $\vdots$ & Sangat Kurang \\
\hline
\end{tabular}

a. Deskripsi Data Hasil Belajar Pretest Siswa Kelas Eksperimen Berikut ini data hasil belajar pretest siswa kelas eksperimen yaitu Kelas VII-4

yang disajikan dalam bentuk tabel distribusi frekuensi dengan menggunakan SPSS v.23:

Tabel 2. Distribusi Frekuensi Data Hasil Belajar Pretest Siswa

\begin{tabular}{|r|r|r|r|r|}
\hline & Frekuensi & Persentase & $\begin{array}{c}\text { Persentase } \\
\text { yang Valid }\end{array}$ & $\begin{array}{c}\text { Persentase } \\
\text { Kumulatif }\end{array}$ \\
\hline Valid 78-87 & 4 & 10.5 & 10.5 & 10.5 \\
$68-77$ & 6 & 15.8 & 15.8 & 26.3 \\
$58-67$ & 14 & 36.8 & 36.8 & 63.2 \\
$48-57$ & 12 & 31.6 & 31.6 & 94.7 \\
$38-47$ & 1 & 2.6 & 2.6 & 97.4 \\
$28-37$ & 1 & 2.6 & 2.6 & 100.0 \\
\hline
\end{tabular}

9 Ibid, hlm 15. 


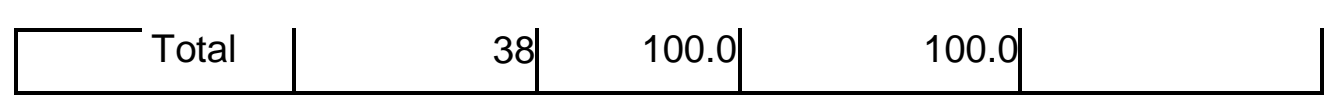

Data yang diperoleh dari pretest hasil belajar siswa di atas digambarkan melalui grafik histogram dengan menggunakan SPSS v.23

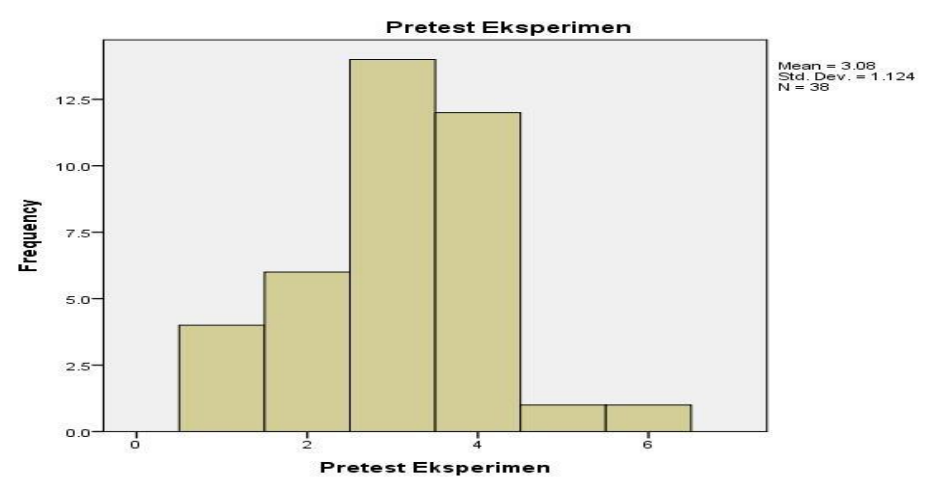

Gambar 1. Histogram Hasil Belajar Pretest Siswa Kelas Eksperimen

Dari grafik histogram di atas dapat dilihat bahwa kelas interval nilai 80-89 terletak pada interval 2 dengan frekuensi 2, 70-79 terletak pada interval 3 dengan frekuensi 7, 60-69 terletak pada interval 4 dengan frekuensi 13 dan 059 terletak pada interval 5 dengan frekuensi 16.

Tabel 3. Deskripsi Data Hasil Belajar Pretest Kelas Eksperimen

\begin{tabular}{|l|r|r|}
\hline $\mathrm{N}$ & Valid & 38 \\
\cline { 2 - 3 } & Missing & 0 \\
\hline Mean & 61.18 \\
Median & 61.00 \\
Mode & 61 \\
Std. Deviation & 11.446 \\
Variance & 131.019 \\
Range & 56 \\
Minimum & 28 \\
Maximum & 84 \\
Sum & 2325 \\
\hline
\end{tabular}


Berdasarkan data yang disajikan pada tabel di atas, diperoleh nilai pemusatan data mean sebesar 61,18 , dengan melihat kriteria penilaian hasil belajar matematika siswa maka data mean termasuk dalam kategori penilaian kurang. Standar deviasi sebesar 11,4. Sehingga dapat disimpulkan bahwa data di atas memusat ke nilai 61,18 dan data tersebut menyebar sebesar $0-11$ satuan dari rata-ratanya.

\section{b. Deskripsi Data Hasil Belajar Pretest Siswa Kelas Kontrol}

Data hasil belajar pretest siswa kelas kontrol yaitu Kelas VII-5 disajikan dalam tabel distribusi frekuensi di bawah ini:

Tabel 4. Distribusi Frekuensi Data Hasil Belajar Pretest Kelas Kontrol

\begin{tabular}{|r|r|r|r|r|}
\hline & Frekuensi & Persentase & $\begin{array}{r}\text { Persentase } \\
\text { yang Valid }\end{array}$ & $\begin{array}{r}\text { Persentase } \\
\text { Kumulatif }\end{array}$ \\
\hline Valid 77-85 & 4 & 10.5 & 10.5 & 10.5 \\
$68-76$ & 5 & 13.2 & 13.2 & 23.7 \\
$59-67$ & 12 & 31.6 & 31.6 & 55.3 \\
$50-58$ & 10 & 26.3 & 26.3 & 81.6 \\
$41-49$ & 6 & 15.8 & 15.8 & 97.4 \\
$32-40$ & 1 & 2.6 & 2.6 & 100.0 \\
Total & 38 & 100.0 & 100.0 & \\
\hline
\end{tabular}

Data yang diperoleh dari pretest hasil belajar siswa di atas digambarkan melalui grafik histogram dengantmermagunakan SPSS v.23, sebagai berikut:

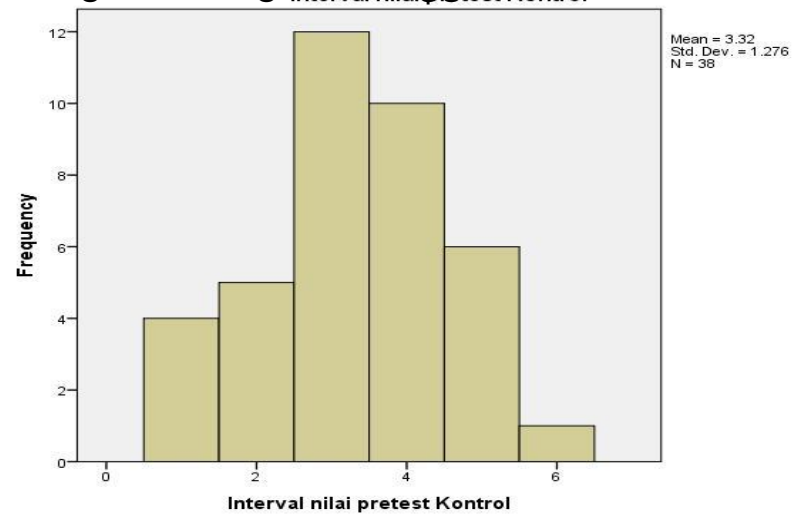

Gambar 2. Histogram Hasil Belajar Pretest Siswa Kelas Kontrol 
Dari grafik histogram di atas dapat dilihat bahwa kelas interval nilai 80-89 terletak pada interval 2 dengan frekuensi 2, 70-79 terletak pada interval 3 dengan frekuensi 5, 60-69 terletak pada interval 4 dengan frekuensi 12 dan 059 terletak pada interval 5 dengan frekuensi 19.

Data nilai pretest hasil belajar matematika siswa pada kelas kontrol dideskripsikan menggunakan SPSS v.23 yang disajikan dalam tabel berikut:

Tabel 5. Deskripsi Data Pretest Hasil Belajar Kelompok Kontrol

\begin{tabular}{|l|l|r|}
\hline $\mathrm{N}$ & Valid & 38 \\
\cline { 2 - 3 } & Missing & 0 \\
\hline Mean & 59.95 \\
Median & 59.50 \\
Mode & $62^{\mathrm{a}}$ \\
Std. Deviation & 11.104 \\
Variance & 123.294 \\
Range & 48 \\
Minimum & 36 \\
Maximum & 84 \\
Sum & 2278 \\
\hline
\end{tabular}

Berdasarkan tabel di atas, diperoleh nilai pemusatan data mean sebesar 59,95 atau dengan pembulatan 60 , data mean termasuk dalam kategori penilaian kurang. Standar deviasi sebesar 11. Sehingga dapat disimpulkan bahwa data di atas memusat ke nilai 60 dan data tersebut menyebar sebesar 0 - 11 satuan dari rata-ratanya.

\section{Deskripsi Data Hasil Belajar Posttest Siswa}

Data posttest dikumpulkan setelah masing-masing kelompok penelitian diberi tindakan atau perlakuan. Data posttest ini merupakan data yang akan diolah untuk pengujian hipotesis penelitian.

a. Deskripsi Data Hasil Belajar Posttest Siswa Kelas Eksperimen Berikut ini data hasil belajar posttest siswa kelas eksperimen yaitu Kelas VII4 yang disajikan dalam bentuk tabel distribusi frekuensi dengan menggunakan SPSS v.23: 
Tabel 6. Distribusi Frekuensi Data Hasil Belajar Posttest Kelas Eksperimen

\begin{tabular}{|r|c|c|c|c|}
\hline & Frekuensi & Persentase & $\begin{array}{c}\text { Persentase } \\
\text { yang Valid }\end{array}$ & $\begin{array}{c}\text { Persentase } \\
\text { Kumulatif }\end{array}$ \\
\hline Valid91-97 & 9 & 23.7 & 23.7 & 23.7 \\
$74-90$ & 10 & 26.3 & 26.3 & 50.0 \\
$70-83$ & 13 & 34.2 & 34.2 & 84.2 \\
$63-69$ & 4 & 10.5 & 10.5 & 94.7 \\
$56-62$ & 1 & 2.6 & 2.6 & 97.4 \\
Total & 38 & 2.6 & 2.6 & 100.0 \\
\hline
\end{tabular}

Data yang diperoleh dari pretest hasil belajar siswa di atas digambarkan melalui grafik histogram dengan menggunakan SPSS v.23 sebagai berikut:

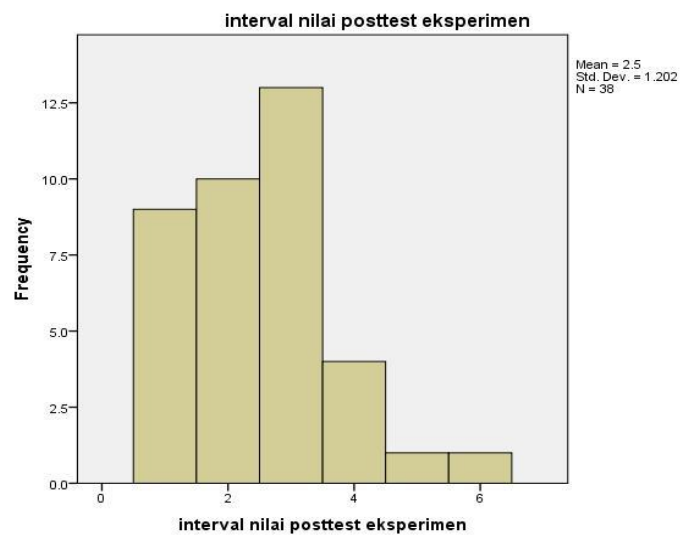

Gambar 3. Histogram Hasil Belajar Posttest Siswa Kelas Eksperimen

Peneliti sajikan gejala pusat data posttest hasil belajar siswa kelas eksperimen dengan menggunakan aplikasi SPSS v.23.

Tabel 7. Deskripsi Data Hasil Belajar Posttest Kelompok Eksperimen

\begin{tabular}{|l|l|r|}
\hline \multirow{2}{*}{$\mathrm{N}$} & Valid & 38 \\
\cline { 2 - 3 } & Missing & 0 \\
\hline Mean & 83.97 \\
Median & 83.50 \\
Mode & $80^{\mathrm{a}}$ \\
Std. Deviation & 8.241 \\
Variance & 67.918 \\
Range & 36 \\
Minimum & 61 \\
Maximum & 97
\end{tabular}


Sum

3191

Berdasarkan tabel do atas, diperoleh nilai pemusatan data mean diperoleh sebesar 83.97, dengan melihat kriteria penilaian hasil belajar matematika siswa maka data mean termasuk dalam kategori penilaian baik. Standar deviasi sebesar

8. Sehingga dapat disimpulkan bahwa data di atas memusat ke nilai 83.97 dan data tersebut menyebar sebesar 0 - 8 satuan dari rata-ratanya.

b. Deskripsi Data Hasil Belajar Posttest Siswa Kelas Kontrol

Berikut ini data hasil belajar posttest siswa kelas kontrol yaitu Kelas VII-5 yang disajikan dalam bentuk tabel distribusi frekuensi dan diolah dengan menggunakan aplikasi SPSS v.23:

Tabel 8. Distribusi Frekuensi Data Hasil Belajar Posttest Kelas Kontrol

\begin{tabular}{|r|r|r|r|r|}
\hline & Frekuensi & Persentase & $\begin{array}{r}\text { Persentase } \\
\text { yang Valid }\end{array}$ & $\begin{array}{c}\text { Persentase } \\
\text { Kumulatif }\end{array}$ \\
\hline Valid 91-97 & 2 & 5.3 & 5.3 & 5.3 \\
$84-90$ & 5 & 13.2 & 13.2 & 18.4 \\
$77-83$ & 8 & 21.1 & 21.1 & 39.5 \\
$70-76$ & 16 & 42.1 & 42.1 & 81.6 \\
$63-69$ & 5 & 13.2 & 13.2 & 94.7 \\
$56-62$ & 2 & 5.3 & 5.3 & 100.0 \\
Total & 38 & 100.0 & 100.0 & \\
\hline
\end{tabular}

Data yang diperoleh dari pretest hasil belajar siswa di atas digambarkan melalui grafik histogram berikut:

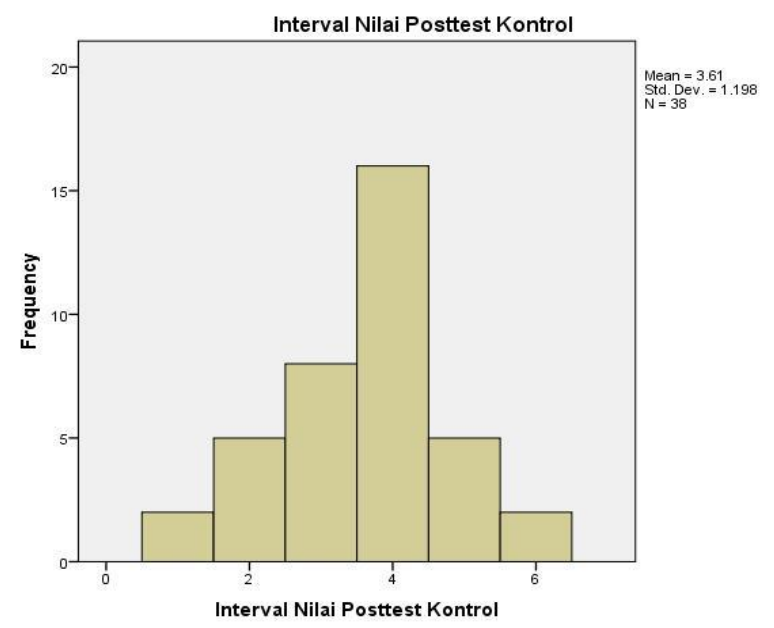


Gambar 4. Histogram Posttest Hasil Belajar Siswa Kelas Kontrol

Peneliti sajikan gejala pusat data posttest hasil belajar siswa kelas kontrol dengan menggunakan aplikasi SPSS v.23.

Tabel 9. Deskripsi Data Posttest Hasil Belajar Kelompok Kontrol

\begin{tabular}{|l|l|r|}
\hline $\mathrm{N}$ & Valid & 38 \\
\cline { 2 - 3 } & Missing & 0 \\
\hline Mean & 75.42 \\
Median & 75.00 \\
Mode & $70^{\mathrm{a}}$ \\
Std. Deviation & 7.835 \\
Variance & 61.385 \\
Range & 34 \\
Minimum & 58 \\
Maximum & 92 \\
Sum & 2866 \\
\hline
\end{tabular}

Sesuai data yang disajikan pada tabel di atas, diperoleh nilai pemusatan data mean diperoleh sebesar 75.42, dengan melihat kriteria penilaian hasil belajar matematika siswa maka data mean termasuk dalam kategori penilaian cukup. Standar deviasi sebesar 8. Sehingga dapat disimpulkan bahwa data di atas memusat ke nilai 75.42 dan data tersebut menyebar sebesar 0 - 8 satuan dari rata-ratanya.

\section{Analisis Data Pretest}

\section{a. Uji Normalitas Data Pretest}

Uji normalitas digunakan untuk mengetahui bahwa data yang diperoleh terdistribusi normal. Pengujian normalitas data dilakukan dengan SPSS v.23 menggunakan Uji Kolmogorov-smirnov dengan taraf signifikansi $5 \%$ atau 0,05. Tabel 10. Hasil Uji Normalitas Data Pretest Kelas Eksperimen dan Kelas Kontrol 


\begin{tabular}{|l|l|r|r|r|r|r|r|}
\hline \multicolumn{9}{|c|}{ Tests of Normality } \\
\hline & \multirow{2}{*}{ Faktor } & \multicolumn{2}{|c|}{ Kolmogorov-Smirnov } & \multicolumn{3}{|c|}{ Shapiro-Wilk } \\
\cline { 3 - 8 } & Statistic & $\mathrm{df}$ & \multicolumn{1}{c|}{ Sig. } & Statistic & df & Sig. \\
\hline \multirow{2}{*}{$\begin{array}{l}\text { data pretest } \\
\text { hasil belajar } \\
\text { siswa }\end{array}$} & Eksperimen & .088 & 38 & $.200^{*}$ & .967 & 38 & .328 \\
\cline { 3 - 8 } & Kontrol & .074 & 38 & $.200^{*}$ & .985 & 38 & .883 \\
\hline
\end{tabular}

Berdasarkan tabel di atas nilai signifikansi $0,200>0,05$ maka data pretest hasil belajar siswa kelompok eksperimen dan kelompok kontrol berdistribusi normal, dapat disimpulkan bahwa data hasil belajar pretest seluruhnya baik eksperimen maupun kontrol ialah berdistribusi normal. Sehingga analisis perbedaan (komparatif) data hasil belajar pretest menggunakan statistik parametris dengan t-test.

\section{b. Uji Homogenitas Data Pretest}

Pengujian hipotesis ini dimaksudkan untuk mengetahui apakah terdapat perbedaan yang signifikan atau tidak pada kemampuan awal siswa antara kelompok belajar eksperimen dengan kelompok belajar kontrol berupa pretest hasil belajar. Hipotesis komparatif data posttest hasil belajar yang akan diuji berdasarkan $\mathrm{n}$ yang sama, yaitu $n_{1}=38$ dan $n_{2}=38$, serta berasal dari populasi/sampel yang tidak berkorelasi (independen). Pengujian homogenitas data pretest hasil belajar diuji menggunakan SPSS v.23 dengan taraf signifikansi 5\% atau 0,05.

Tabel 11. Hasil Uji Homogenitas Data Pretest

\begin{tabular}{|ll|r|r|r|r|}
\hline & & $\begin{array}{r}\text { Levene } \\
\text { Statistic }\end{array}$ & df1 & df2 & Sig. \\
\hline $\begin{array}{llll}\text { data pretest hasil } \\
\text { belajar siswa }\end{array}$ & $\begin{array}{l}\text { Based on Mean } \\
\text { Based on Median }\end{array}$ & .900 & 1 & 74 & .346 \\
& $\begin{array}{l}\text { Based on Median and } \\
\text { with adjusted df }\end{array}$ & .896 & 1 & 74 & .347 \\
& $\begin{array}{l}\text { Based on trimmed } \\
\text { mean }\end{array}$ & .899 & 1 & 73.96 & .347 \\
& & & .346 \\
\hline
\end{tabular}

Kriteria pengambilan hipotesis uji homogenitas berdasarkan SPSS v.23:

1) Jika nilai signifikansi (sig.) Based On Mean > 0,05, maka varian data adalah homogen.

2) Jika nilai signifikansi (sig.) Based On Mean < 0,05, maka varian data adalah tidak homogen.

Berdasarkan perolehan hasil di atas sesuai dengan kriteria yang berlaku diketahui nilai signifikansi Based on Mean adalah sebesar 0,346 >0,05. Sehingga 
dapat disimpulkan bahwa varians data hasil belajar pretest kelompok eksperimen dan kelompok kontrol adalah sama atau homogen. Sehingga analisis perbedaan (komparatif) data hasil belajar pretest menggunakan statistik parametris dengan t-test.

c. Uji Kesamaan Rata-rata (t-test) Data Hasil Belajar

Hasil penelitian data hasil belajar pretest kelompok eksperimen dan

kelompok kontrol berdistribusi normal dan homogen maka untuk menguji hipotesis menggunakan uji t-test menggunakan rumus polled varian. Peneliti menggunakan SPSS v.23 untuk mempermudah perhitungan.

Tabel 12. Hasil Uji T-test Pretest Hasil Belajar Siswa

\begin{tabular}{|l|l|r|r|r|c|}
\hline & Kelas & $\mathrm{N}$ & Mean & $\begin{array}{c}\text { Std. } \\
\text { Deviation }\end{array}$ & $\begin{array}{c}\text { Std. Error } \\
\text { Mean }\end{array}$ \\
\hline Hasil Belajar & Eksperimen & 38 & 61.18 & 11.446 & 1.857 \\
Pretest & Kontrol & 38 & 59.95 & 11.104 & 1.801 \\
\hline
\end{tabular}

Independent Samples Test

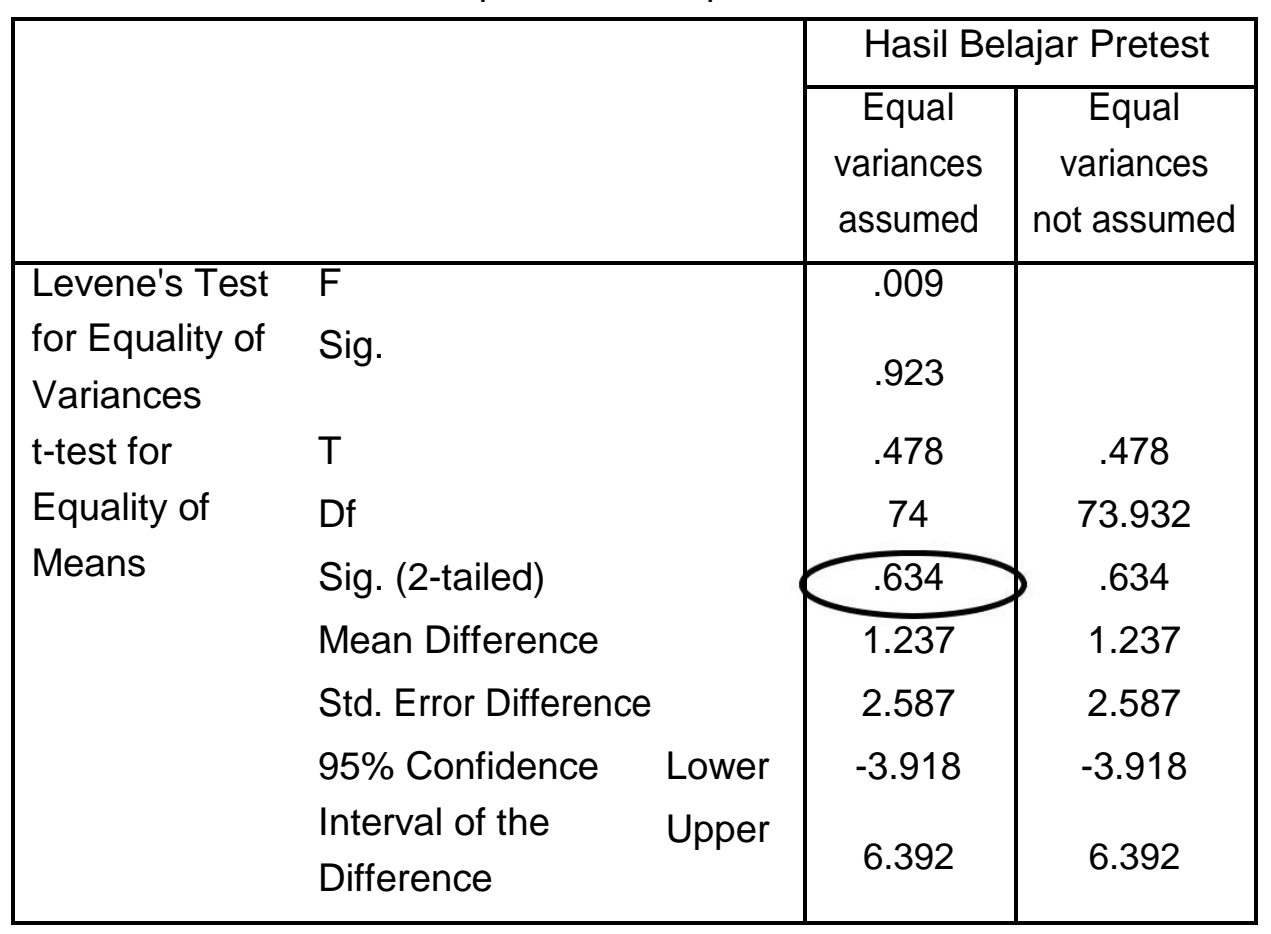

Berdasarkan hasil perhitungan SPSS di atas diperoleh nilai signifikansi (sig. (2-tailed)) sebesar 0,634 > 0,05, maka sesuai dengan dasar pengambilan keputusan dari Uji Independent Sample $T$-test, maka dapat disimpulkan bahwa $\mathrm{H}_{0}$ 
diterima yang artinya bahwa tidak ada perbedaan antara rata-rata hasil belajar kelompok kontrol dan kelompok eksperimen. Oleh karena itu dapat diketahui bahwa antara kelompok kontrol dan kelompok eksperimen memiliki kemampuan awal yang sama khususnya dalam hasil belajarnya.

\section{Analisis Data Posttest}

a. Uji Normalitas Data Posttest Hasil Belajar

Uji normalitas digunakan untuk mengetahui bahwa data yang diperoleh dari masing-masing kelas eksperimen maupun kelas kontrol berdistribusi normal. Pengujian normalitas data dilakukan dengan SPSS v.23 menggunakan Uji Kolmogorov-smirnov dengan taraf signifikansi 5\% atau 0,05.

Tabel 13. Hasil Uji Normalitas Data Posttest Hasil Belajar Siswa

\begin{tabular}{|l|l|r|r|l|r|r|r|}
\hline & \multirow{2}{*}{ Factor } & \multicolumn{3}{|c|}{ Kolmogorov-Smirnov } & \multicolumn{3}{|c|}{ Shapiro-Wilk } \\
\cline { 3 - 8 } & & Statistic & df & Sig. & Statistic & df & Sig. \\
\hline data posttest & Eksperimen & .115 & 38 & $.200^{*}$ & .960 & 38 & .193 \\
hasil belajar & Control & .078 & 38 & $.200^{*}$ & .989 & 38 & .962 \\
\hline
\end{tabular}

Berdasarkan tabel di atas nilai signifikansi menunjukkan nilai 0,200 > 0,05 maka data posttest hasil belajar siswa kelompok eksperimen dan kelompok kontrol berdistribusi normal.

Jadi dapat disimpulkan bahwa data hasil belajar pretest seluruhnya baik eksperimen maupun kontrol ialah berdistribusi normal. Sehingga pengujian hipotesis komparatif (uji perbedaan rata-rata) data posttest hasil belajar menggunakan statistik parametrik.

\section{b. Uji Homogenitas Data Posttest Hasil Belajar}

Pengujian hipotesis ini dimaksudkan untuk mengetahui apakah terdapat perbedaan yang signifikan atau tidak pada kemampuan akhir siswa berupa hasil belajar setelah diberikan perlakuan. Hipotesis komparatif data posttest hasil belajar yang akan diuji berdasarkan $n$ yang sama, yaitu $\mathrm{n}_{1}=38$ dan $\mathrm{n}_{2}=$ 38, serta berasal dari populasi/sampel yang tidak berkorelasi (independen). Pengujian homogenitas data posttest hasil belajar diuji menggunakan SPSS v.23 dengan taraf signifikansi $5 \%$ atau 0,05.

Tabel 14. Hasil Uji Homogenitas Data Posttest

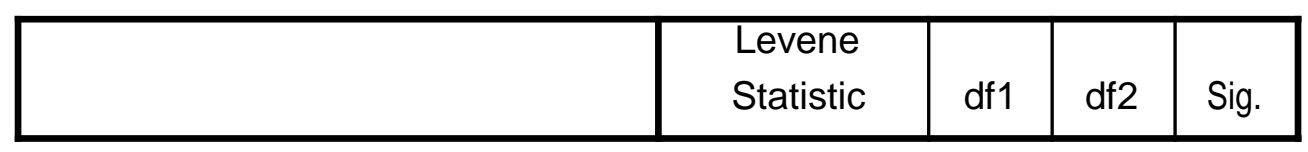




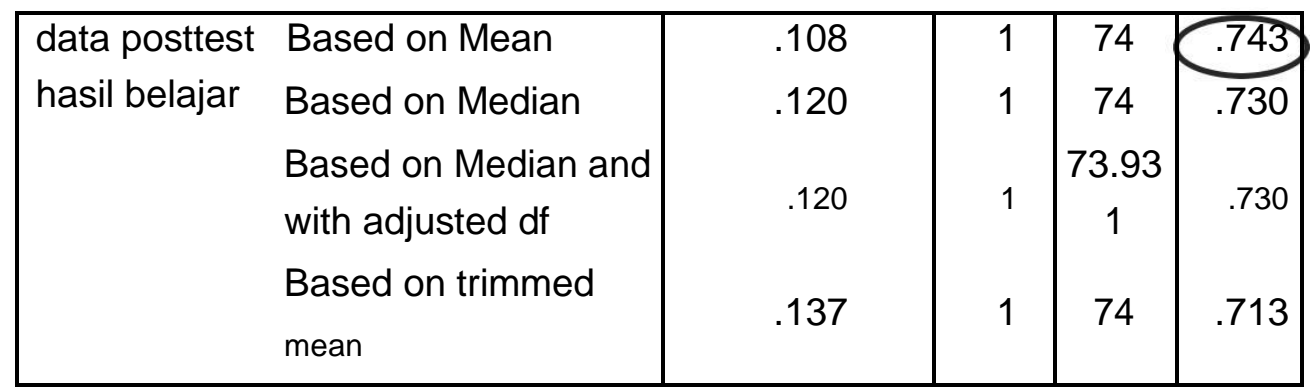

Berdasarkan perolehan hasil di atas sesuai dengan kriteria yang berlaku diketahui nilai signifikansi Based on Mean adalah sebesar 0,743>0,05. Sehingga dapat disimpulkan bahwa varians data hasil belajar posttest kelompok eksperimen dan kelompok kontrol adalah sama atau homogen.

c. Uji Perbedaan Rata-rata

Uji hipotesis menggunakan uji perbedaan rata-rata dengan kriteria:

1 : rata-rata hasil belajar pada materi segiempat (persegi panjang dan persegi) dengan menggunakan model pembelajaran kooperatif tipe Make $A$ Match dengan berbantuan media grafis lebih baik dari rata-rata hasil belajar pada materi segiempat (persegi panjang dan persegi) dengan tanpa menggunakan model pembelajaran kooperatif tipe Make A Match dengan berbantuan media grafis.

0 : rata-rata hasil belajar pada materi segiempat (persegi panjang dan persegi) dengan menggunakan model pembelajaran kooperatif tipe Make $A$ Match dengan berbantuan media grafis tidak lebih baik dari rata-rata hasil belajar pada materi segiempat (persegi panjang dan persegi) dengan tanpa menggunakan model pembelajaran kooperatif tipe Make A Match dengan berbantuan media grafis.

Karena $n$ yang sama $\left(n_{1}=n_{2}\right)$ dan varian data homogen, maka pengujian t-test menggunakan rumus polled varian. Peneliti menggunakan aplikasi SPSS v.23 untuk mempermudah perhitungan.

Tabel 15. Hasil Uji T-test Posttest Hasil Belajar Siswa

\begin{tabular}{|l|l|r|r|r|r|}
\hline & Factor & $\mathrm{N}$ & Mean & $\begin{array}{c}\text { Std. } \\
\text { Deviation }\end{array}$ & $\begin{array}{c}\text { Std. Error } \\
\text { Mean }\end{array}$ \\
\hline data posttest & Eksperimen & 38 & 83.97 & 8.241 & 1.337 \\
hasil belajar & Control & 38 & 75.42 & 7.835 & 1.271 \\
\hline
\end{tabular}




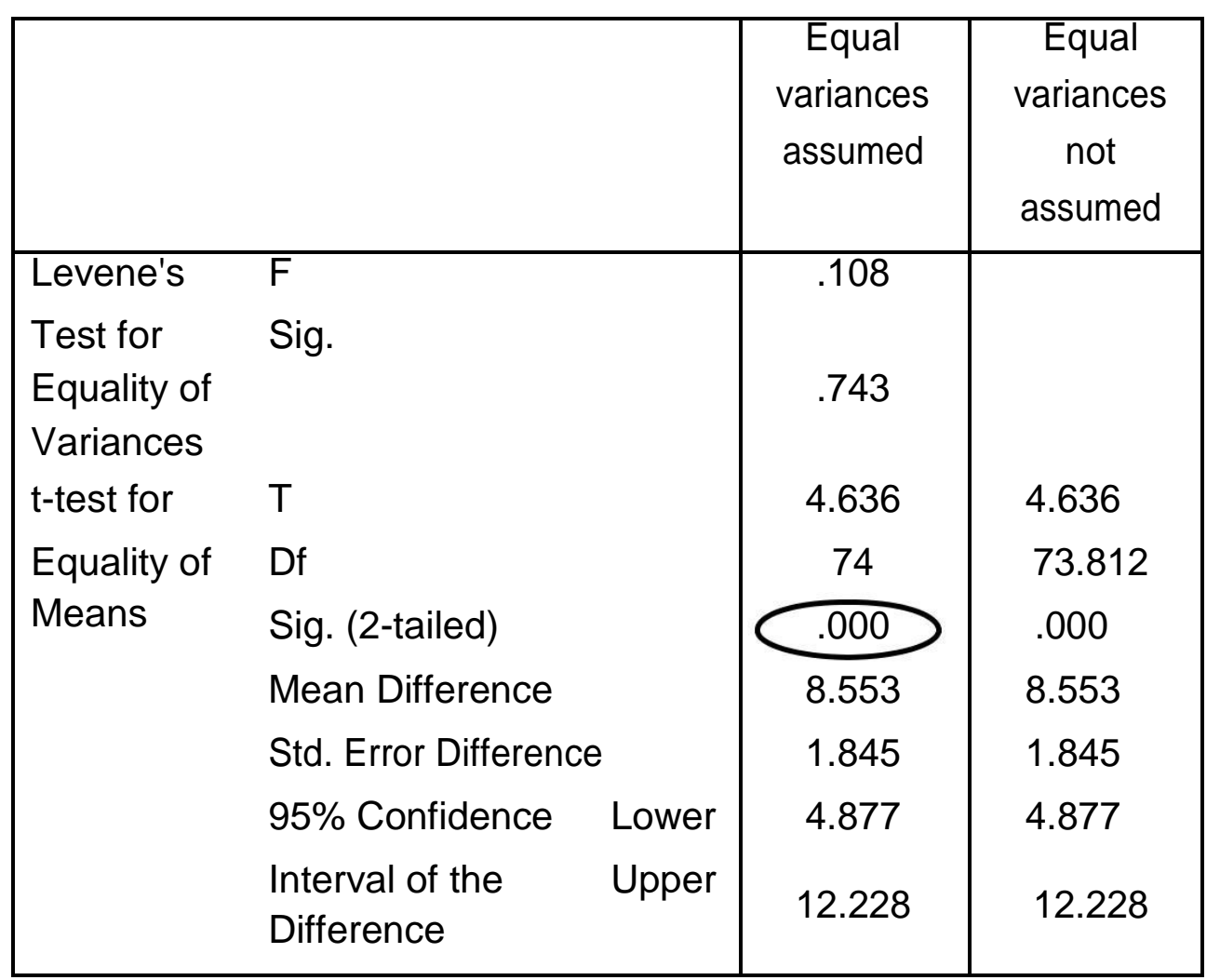

Berdasarkan hasil perhitungan SPSS di atas diperoleh nilai sig. (2-tailed) sebesar $0,000<0,05$ atau dengan melihat nilai $T_{\text {hitung }}>T_{\text {tabel }}$ yaitu 4,636 $>$ 1,993, maka sesuai dengan dasar pengambilan keputusan dari Uji Independent Sample $T$-test, maka dapat disimpulkan bahwa $H_{1}$ diterima, yang artinya ada pengaruh yang signifikan antara model pembelajaran kooperatif tipe Make $A$ Match berbantuan media grafis terhadap hasil belajar siswa pada materi pokok segiempat di kelas VII MTs Negeri Model Padangsidimpuan.

\section{PEMBAHASAN}

Penelitian ini dilakukan peneliti untuk mengetahui pengaruh model pembelajaran kooperatif tipe Make A Match berbantuan media grafis terhadap hasil belajar siswa pada materi pokok segiempat di kelas VII MTs Negeri Model Padangsidimpuan.

Berdasarkan hasil penelitian menunjukkan bahwa kedua kelas baik kelas eksperimen maupun kelas kontrol dimulai pada saat kondisi yang seimbang dan sama yang diketahui setelah dilakukan uji normalitas dan uji homogenitas pada pretest, dilihat dari hasil belajar rata-rata kelas eksperimen $=61,5$ dan nilai ratarata hasil belajar kelas kontrol $=60$. Artinya kedua kelas baik kelas eksperimen 
maupun kelas kontrol terlihat tidak ada perbedaan yang signifikan antara kemampuan awal siswa.

Setelah diberikan pretest dan telah diketahui hasilnya, kelas eksperimen diberikan perlakuan dengan menerapkan model pembelajaran kooperatif tipe Make a Match berbantuan media grafis dan kelas kontrol diberikan pembelajaran berpusat pada guru.

Pada saat pembelajaran berlangsung, siswa di kelas kontrol kurang tertarik terhadap materi pelajaran yang diberikan, mereka jarang merespon dan memberikan reaksi terhadap apa yang disampaikan pada saat proses belajar mengajar berlangsung. Ketika guru bertanya kepada para siswa, 93\% siswa hanya terdiam saja tanpa menjawab. Ketika guru meminta siswa untuk maju ke depan kelas untuk menunjukkan unsur-unsur dari segiempat hanya $7 \%$ siswa yang maju dengan inisiatifnya sendiri. Guru harus menunjuk siswa agar mau maju ke depan untuk memberikan pendapatnya. Siswa kelas kontrol cenderung tidak memberikan perhatian yang besar terhadap pelajaran. Hal tersebut terlihat dari senangnya siswa bermain dengan teman semejanya daripada harus memperhatian guru yang sedang menjelaskan materi di depan kelas.

Keterlibatan siswa di kelas kontrol sangat kurang, dikarenakan tidak adanya media yang digunakan. Kegiatan pembelajaran melalui indera lain tidak dapat dicapai. Pada saat pembelajaran di kelas kontrol, siswa cenderung pasif sehingga dapat mengakibatkan hasil belajar siswa kelas kontrol tidak optimal.

Berbeda dengan kegiatan pembelajaran di kelas eksperimen. Saat pembelajaran di kelas eksperimen terlihat semangat para siswa dalam menerima materi pelajaran. Siswa sangat antusias ketika guru mulai membagi kelompok belajar, memberikan LAS dan membagi kartu make a match kepada masing-masing kelompok. Setiap kelompok aktif dalam menjawab soal yang ada di LAS dengan dibantu oleh media grafis yaitu media gambar mengenai materi pelajaran segiempat utnuk memudahkan siswa dalam menjawab soal-soal tersebut. Sebagian besar siswa menajawab pertanyaan tersebut dengan benar. Dan secara langsung model pembelajaran kooperatif tipe make a match ini mampu mengaktifkan kegiatan pembelajaran. Siswa dapat merespon materi pelajaran ayng diberikan dengan baik dan memberikan reaksi terhadap apa ayng disampaikan oleh guru.

Berdasarkan hasil uji t hasil belajar yang dilakukan oleh peneliti diperoleh bahwa thitung < tabel. Variabel hasil belajar diuji dengan rumus Polled varian karena kedua sampel homogen dan jumlah $\mathrm{n}$ sama, maka didapat hasilnya thitung $<t_{\text {tabel }}(0,000<0,05)$ yang artinya $H_{1}$ diterima. 


\section{PENUTUP}

Berdasarkan hasil penelitian dan analisis data, maka peneliti mengambil kesimpulan bahwa ada pengaruh signifikan antara penggunaan model pembelajaran kooperatif tipe Make a Match berbantuan media grafis terhadap hasil belajar siswa pada pokok bahasan segiempat di kelas VII MTs Negeri Model Padangsidimpuan. Hal ini ditunjukkan dari hasil uji hipotesis yang menunjukkan bahwa nilai sig.(2-tailed) sebesar 0,000 $<0,05$ atau dengan melihat nilai thitung $>$ tabel $(4,636>1,993)$. Dari perhitungan tersebut jelas terlihat penerimaan $H_{1}$. Artinya nilai rata-rata hasil belajar aspek kemampuan kognitif siswa pada materi segiempat dengan menggunakan model pembelajaran kooperatif tipe Make a Match dengan berbantuan media grafis lebih baik dari rata-rata hasil belajar pada materi pokok segiempat (persegi panjang dan persegi) dengan tanpa menggunakan model pembelajaran kooperatif tipe Make a Match dengan berbantuan media grafis.

\section{DAFTAR PUSTAKA}

Agus Rianto, Statistik: Konsep Dasar, Aplikasi dan Pengembangannya, Jakarta: Kencana, 2004.

Anas Sudijono, Pengantar Evaluasi Pendidikan, Jakarta: Rajawali Pers, 2011.

Asep Jihad dan Abdul Haris, Evaluasi Pembelajaran, Yogyakarta: Multi Pressindo, 2012.

Asrul, dkk., Evaluasi Pembelajaran, Medan: Citapustaka Media, 2015.

Basyiruddin Usman dan Asnawir, Media Pembelajaran, Jakarta: Ciputat Pers, 2002.

Darwyan Syah, dkk, Pengantar Statistik Pendidikan, Jakarta: Putra Grafika, 2009.

Departemen Agama RI, Al-Qur'an Tajwid dan Terjemah, Bandung: CV Penerbit Diponegoro.

Dimyati dan Mudjiono, Belajar dan Pembelajaran, Jakarta: Rineka Cipta, 2006.

Duwi Priyatno, SPSS 22: Pengolahan Data Terpraktis, Yogyakarta: ANDI, 2014.

Hamdani, Strategi Belajar Mengajar, Bandung: Pustaka Setia, 2011.

Isjoni, Cooperative Learning, Bandung: Alfabeta, 2014.

Istarani, 58 Model Pembelajaran Inovatif, Medan: Media Persada, 2011. 
M. Cholik Adinawan dan Sugijono, Matematika, Jakarta: Erlangga, 2007.

Masitoh, dan Laksmi Dewi, Strategi Pembelajaran, Jakarta: Dirjen Pendidikan Islam Depag RI, 2009.

Nana Sudjana, Penilaian Hasil Belajar Mengajar, Bandung: Remaja Rosdakarya, 2001.

, Penilaian Hasil Proses Belajar Mengajar, Bandung: Remaja Rosdakarya, 1999.

Ngalim Purwanto, Prinsip-Prinsip dan Teknik Evaluasi Pengajaran, Bandung: Remaja Rosdakarya, 2001.

Rangkuti, Ahmad Nizar, Metode Penelitan Pendidikan (Pendekatan Kuantitatif, Kualitatif, PTK dan Penelitian Pengembangan), Bandung: Citapustaka Media, 2015.

Rusman, Model-model Pembelajaran, Jakarta: Rajagrafindo Persada, 2012.

Sardiman, Interaksi dan Motivasi Belajar-Mengajar, Jakarta: Rajagrafindo Persada, 2011.

Sugiyono, Metode Penelitian Administrasi, Bandung: Alfabeta, 2010.

Suharsimi Arikunto, Dasar-dasar Evaluasi Pendidikan, Jakarta: Bumi Aksara, 2012. , Prosedur Penelitian Suatu Pendekatan Praktik, Jakarta: Rineka Cipta, 2006.

Trianto, Mendesain Model Pembelajaran Inovatif-Progresif: Konsep, Landasan dan Implementasinya pada Kurikulum Tingkat Satuan Pendidikan (KTSP), Jakarta: Kencana, 2009.

Undang-undang Sistem Pendidikan Nasional, Yogyakarta: Pustaka Pelajar, 2005.

Wina Sanjaya, Perencanaan dan Desain Sistem Pembelajaran, Jakarta: Kencana Prenada Media Group, 2008.

, Strategi Pembelajaran Berorientasi Standar Proses Pendidikan, Jakarta: Kencana, 2010.

Duwi Priyatno, SPSS 22: Pengolahan Data Terpraktis, Yogyakarta: ANDI, 2014. 